\section{Green Taxation}

Ana Clara Borrego ${ }^{1}$ and Francisco Carreira ${ }^{2}$ ${ }^{1}$ Instituto Politécnico de Portalegre, Portalegre, Portugal

${ }^{2}$ Instituto Politécnico de Setúbal, Setúbal, Portugal

\section{Synonyms}

Eco taxes; Environmental taxes; Green taxes; Pigouvian taxes

\section{Definition}

Green Taxation, also known as Environmental Taxation, involves the use of taxation to promote more responsible environmentally taxpayers' behavior, through tax penalties, in order to punish the polluting behavior, or tax benefits to encourage good behaviors. Definitions of this concept can also be found outside the scientific context, for instance, according to the Carbon Brief Staff (2013) this concept ". . . is commonly used to refer to a package of government measures intended to encourage expansion of low-carbon power, subsidise home insulation and tackle fuel poverty." Additionally, the United Kingdom Government (2012) states that "Environmental taxes are defined as those which meet all of the following three principles: (i) the tax is explicitly linked to the government's environmental objectives; (ii) the primary objective of the tax is to encourage environmentally positive behaviour change; (iii) the tax is structured in relation to environmental objectives, for example: the more polluting the behaviour, the greater the tax levied."

Moreover, the concept of green taxation is inextricably linked with the concept of Green Tax Reform. This type of tax reform seeks to introduce environmental taxes, thereby replacing much of the traditional taxation on companies (income and capital), labor income, and contributions to social security systems, in order to reduce unemployment levels (Álvarez et al. 1998; Alves and Palma 2004). Thus, the Green Tax Reforms presuppose the obtaining of a double gain, denominated by effect of the "double dividend": the environmental gain and the reduction of unemployment, by tax relief on labor.

\section{Introduction}

The idea of taxing pollution is not new, its first reference is associated with the British economist Arthur Cecil Pigou, in 1920, that is why the green taxation is also known as Pigouvian Taxes (Sandmo 2003).

The "polluter-pays principle" is a generally accepted basic principle of environmental law, which was partly based on that old idea of taxing pollution. This principle has two different currents concerning to its application form: on the one 
hand, those who defend its direct application, in particular through greenhouse gas emission quotas; on the other hand, those who support the indirect payment, mainly through environmental taxes that penalize polluting behavior.

In this scope, since the 1990s, most studies on Green Taxation intend to ascertain the best way to apply the "polluter-pays principle": the direct application or the use of Green Taxation. Thus, several authors developed studies, mainly based on mathematical models of general equilibrium, where they conclude that the application of Green Taxation results in better environmental results than the use of direct environmental tools, such as greenhouse gas emission quotas (Baranzini et al. 2000; Goulder et al. 1999; Hong 2015; Sandmo 2003).

The importance of taxation as an environmental "tool" was recognized in the academic context but also by several organizations with key roles in the international environmental context, such as the EU (European Union) and the OECD (Organization for Economic Cooperation and Development), in consequence, it has been extended to a great number of countries.

Despite the widespread use of Green Taxation by countries not belonging to the European Community, in fact it is based on a reform advocated in the European Union in 1993. Thus, the European Union's "White Paper on growth, competitiveness and employment," known, as already referred to, as Green Tax Reform, relies on the following assumptions: (i) introduction of green taxes that substitute the traditional forms of taxation; (ii) integrated economic and environmental objectives; (iii) use of taxation as an environmental "tool"; (iv) obtaining of a double positive effect, referred to in the literature as the "double dividend," that is, to obtain, also, economic gains, for instance, by reducing unemployment, through social security contributions reduction (Álvarez et al. 1998; Borrego 2016; Bovenberg and Mooij 1995).

In relation to the "double dividend" effect: the "first dividend," that is, the environmental gain, is consensual in the previous literature; however, the "second dividend" is a controversial issue in academia.
In relation to the authors who defend the existence of a second positive gain, there are two lines of research around the type of gain, with, on one hand, the European authors defending that the second dividend is the decrease in the levels of unemployment and, on the other hand, the North American authors defending that the second dividend are the gains of efficiency and competitiveness of the economy (Bovenberg and Mooij 1995; Lee and Misiolek 1986; Terkla 1984).

There are also some authors who question the existence of a positive impact on employment, or on the economy, provoked by the introduction of green taxation: some of them conclude that this "second dividend" does not exist, others verify that the second impact exists, however, it is negative, that is, the Green Taxation has a negative impact on employment or on economy, mainly because that type of taxation affects the consumption.

Despite this controversy over the "second dividend," some studies have gone further and point to the existence, in some countries, of a "third dividend". Thus, in recent years, in studies on developing countries, as well as in some countries with major problems of budgetary stability, has been identified another gain: "the reduction of poverty" or "the budgetary balance" (Heerden et al. 2006; Pereira and Pereira 2014).

The analysis, classification, and evolution of green taxation have also been the subject of studies in some countries (Álvarez et al. 1998; Barde and Owens 1996; Borrego 2016; Carreira et al. 2007). For instance, Barde and Owens $(1996,11)$ conducted a study on the application of eco-taxes in OECD countries and found that in those countries "The 'greening' of taxes can be done in two complementary ways. One involves the restructuring of existing taxes by raising the relative prices of products $(. .$.$) that generate more$ pollution (...). A second approach is to introduce new 'eco-taxes' specifically aimed at raising the prices of products which create pollution..." and Álvarez et al. (1998) evaluated the type of Green Tax Reform in some pioneer countries in its implementation and proceeded to its classification. According to these authors the Green Tax Reforms can assume two different types, 
depending on the extent of the reforms implemented: Partial Reforms (adaptation of the existing tax system to give it an environmental concern) or Integrated Reforms (giving rise to an innovative tax system, where environmental taxation plays a major and preponderant role). Some Nordic countries as the Netherlands, Denmark, and Sweden have been pioneers in the implementation of integrated Green Tax Reforms. Borrego (2016) replicated the study of Álvarez et al. (1998) in Portugal and classified Portuguese green tax reform as a partial one. Carreira et al. (2007) analyzed the Portuguese tax legislation and found that the tax system was beginning to show signs of environmental concerns.

There are also studies that refer to the resistance of organized industrial lobbies against the application of Green Taxation. In this context, Daugbjerg and Svendsen (2001) and Svendsen et al. (2001) argue that Green taxation is against the interests of the polluters and some of them can easily mobilize resources to move political influences, in order to put barriers to such type of taxation.

In addition, in the last years, a few studies, that aim to quantify the impact of Green Taxation on the environment, have also emerged (Alberini and Bareit 2017; Ciccone 2014; d'Haultfoeuille et al. 2014). For instance d'Haultfoeuille et al. (2014) analyzed the effect of the introduction in France, in 2008, of a bonus/malus system (tax benefits or penalties) on car purchasing: for the least polluting, it was conceded a benefit and for the most polluting it was applied a penalty. The authors found that this environmental tax measure had a negative effect on the environment, as the measure was poorly designed and still applied benefits to the purchase of vehicles that had a considerably high level of pollution. Alberini and Bareit (2017) replicated an identical study in Switzerland and obtained similar conclusions. Cioccone (2014) sought to assess the impact of the tax penalty on the purchase of polluting vehicles introduced, in Norway, in 2007, to the purchase of new, lesspolluting vehicles, and found that the impact had been positive on the increase in the purchase of less polluting vehicles.
Lastly, it is relevant to understand this topic from a previous literature perspective, but also to understand its potential for future research. In the context of Green Taxation, there are several future research lines that can be explored, from which the following should be highlighted.

Based on the concern for the planet's sustainability and the relation between green taxation and the circular economy, it is necessary to identify the green tax reforms performed by the different countries or regions, in order to assess how they actually contribute to the environmental preservation.

At the same time, in a close relationship between green taxation and Circular Economy, it is important to analyze how green taxes contributed to effective changes in economic agents and consumers' behavior, by influencing their investment decisions, manufacturing and exploration methods, consumer habits, among other attitudes/decisions with environmental impact.

It is not, therefore, enough the creation of green tax measures; it is necessary to monitor their impact in the environmental context, seeking to understand the determinants of their success or failure, contextualized in the cultural, environmental, and even historical specificities of the countries. Thus seeking to contribute to the creation of innovative environmental tax policies, but also assertive in the objectives that they intend to achieve.

It is also important to bear in mind that, in relation to environmental tax measures aimed at promoting more environmentally responsible citizens and companies' behavior, the greater the environmental success of the measure, the biggest is its tax "cost," so it is important to quantify the amount of uncollected tax or of the tax benefit granted to understand its impact on tax revenue.

It is important to highlight that a new methodological approach is desirable, leading to the construction of an index of green taxes, which aims to measure the contribution of a tax system (or specific tax) to the preservation of the environment, which will allow the analysis of the evolution, both in relation to the same country and between countries. 


\section{Key Issues}

The Green Taxation, in the law context, is classified, as referred to by Nabais (2005), as a form of State intervention in favor of the fight for environmental protection and it falls within the sphere of extra-taxation, that is "a set of rules which only formally form part of the tax law, because their main or dominant purpose is the attainment of certain economic or social results and not the obtaining of revenues to cover public expenditure" (Translated from Nabais 2005, 336).

In the tax systems context, Green Taxation may be the result of an integrated tax reform, that is, by substituting the traditional taxation, or alternatively, it may appear as additional rules to traditional taxes without replacing them. In addition, green taxation can take the form of taxation on consumption, corporate, and individual taxation, among other forms.

\section{Summary}

Green taxation is the use of taxation to encourage taxpayers' good behavior in the environmental context. Green taxation is thus a powerful tool for the environment. Taxpayers, in order to obtain tax benefits or to avoid paying higher taxes or fees, adopt more environmentally responsible behavior.

\section{Cross-References}

Business Taxes
Circular Economy
Environmental Factors and Their Impacts on
the Taxes
Environmental Management
- Environmental Sustainability
- Sustainable Competiveness

\section{References}

Alberini, A., \& Bareit, M. (2017). The effect of registration taxes on new car sales and emissions: Evidence from Switzerland. Resource and Energy Economics, 56, 96-112. https://doi.org/10.1016/j.reseneeco.2017.03.005.

Álvarez, X. C., Gago, A., \& Labandeira, X. (1998). Green tax reform: Facts and experiences. Australian Tax Forum, 14(3), 361-379.

Alves, M. R., \& Palma, C. (2004). Impostos ambientais e o duplo dividendo: Experiências europeias. [Working Papers de Economia $\mathrm{N}^{\circ}$ 14]. Universidade de Aveiro, Aveiro. http://econpapers.repec.org/RePEc:ave:wpaper :142004. Accessed 4 January 2018.

Baranzini, A., Goldenberg, J., \& Speck, S. (2000). A future for carbon taxes. Ecological Economics, 32(3), 395-412. https://doi.org/10.1016/S0921-8009(99)001 22-6.

Barde, J. P., \& Owens, J. (1996). The evolution of ecotaxes. The OECD Observer, (198), 11. Organisation for Economic Cooperation and Development.

Borrego, A. C. (2016). Diploma da Fiscalidade Verde Finalmente uma fiscalidade ambiental integrada em Portugal? Revista de Gestão Social e Ambiental, 10(3), 51-68. https://doi.org/10.24857/rgsa.v10i3.1163.

Bovenberg, A. L., \& Mooij, R. A. (1995). Environmental taxes, international capital mobility, and inefficient tax systems: Tax burden $v s$ tax shifting. International Tax and Public Finance, 5, 7-39.

Carbon Brief Staff. (2013). Analysis: What are green taxes, could they be scrapped, and what would the effect be. Carbon Brief, Clear on Climate. https://www. carbonbrief.org/analysis-what-are-green-taxes-couldthey-be-scrapped-and-whatwould-the-effect-be. Accessed 5 September 2017.

Carreira, F. A., Peixe, F., \& Lima, R. (2007). A Fiscalidade e o Ambiente: O Caso Português. Ciência e Técnica Fiscal, 420, 301-342.

Ciccone, A. (2014). Is it all about CO2 emissions? The environmental effects of a tax reform for new vehicles in Norway (No. 19/2014). Memorandum, Department of Economics, University of Oslo. https://www.econstor. eu/handle/10419/119548. Accessed 6 September 2017.

d'Haultfoeuille, X., Givord, P., \& Boutin, X. (2014). The environmental effect of green taxation: The case of the french bonus/malus. The Economic Journal, 124(578). https://doi.org/10.1111/ecoj.12089.

Goulder, L. H., Parry, I., Williams, R. C., III, \& Burtraw, D. (1999). The cost - Effectiveness of alternative instruments for environmental protection in a second-best setting. Journal of Public Economics, 72(3), 329-360. https://doi.org/10.1016/S0047-2727(98)00109-1.

Heerden, J. V., Gerlagh, R., Blignaut, J., Horridge, M., Hess, S., Mabugu, R., \& Mabugu, M. (2006). Searching for triple dividends in South Africa: Fighting $\mathrm{CO}_{2}$ pollution and poverty while promoting growth. The Energy Journal, 27(2), 113-141. 
Lee, D. R., \& Misiolek, W. S. (1986). Substituing pollution taxation for general taxation: Some implications for efficiency in pollution taxation. Journal of Environmental Economics and Management, 13, 338-347. https://doi.org/10.1016/0095-0696(86)90004-5.

Nabais, J. C. (2005). Por um Estado Fiscal Suportável. Estudos de Direito Fiscal. Coimbra: Almedina.

Pereira, A. M., \& Pereira, R. M. (2014). Environmental fiscal reform and fiscal consolidation: The quest for the third dividend in Portugal. Public Finance Review, 42(2), 222-253. https://doi.org/10.1177/1091142113485803.

Terkla, D. (1984). The efficiency value of effluent tax revenues. Journal of Environmental Economics Management, 11, 107-123. https://doi.org/10.1016/00950696(84)90010-X.

United Kingdom Government. (2012). Definition of environmental tax published. https:/www.gov.uk/govern ment/news/definition-of-environmental-tax-published. Accessed 5 September 2017.

\section{Readings}

Daugbjerg, C., \& Svendsen, G. (2001). Designing green taxes in a political context: From optimal to feasible environmental regulation. 5th Nordic environmental research conference: The Ecological Modernisation Society. www.hha.dk/nat/WPER/01-17_gts.pdf. Accessed 28 April 2018.

Hong, L. C. (2015). Investigation into what the Malaysian Public wants from environmental protection tax laws in Malaysia. In International conference on accounting studies, Johor. https://www.researchgate.net/publica tion/281628882_INVESTIGATION_INTO_WHAT THE_MALAYSIAN_PUBLIC_WANTS_F FOM_E NVIROANMENT_PRŌTECTION_TAX_LAWS_IN_ MALAYSIA. Accessed 28 September 2017.

Sandmo, A. (2003). Environmental taxation and revenue for development. [Discussion paper: World Institute for Development Economics Research, 2003/86,1-27]. http://www.wider.unu.edu/stc/repec/pdfs/rp2003/dp2 003-86.pdf. Accessed 2 July 2015.

Svendsen, G. T., Daugbjerg, C., Hjøllund, L., \& Pedersen, A. B. (2001). Consumers, industrialists and the political economy of green taxation: $\mathrm{CO} 2$ taxation in OECD. Energy Policy, 29(6), 489-497. https://doi.org/ 10.1016/S0301-4215(00)00145-2. 